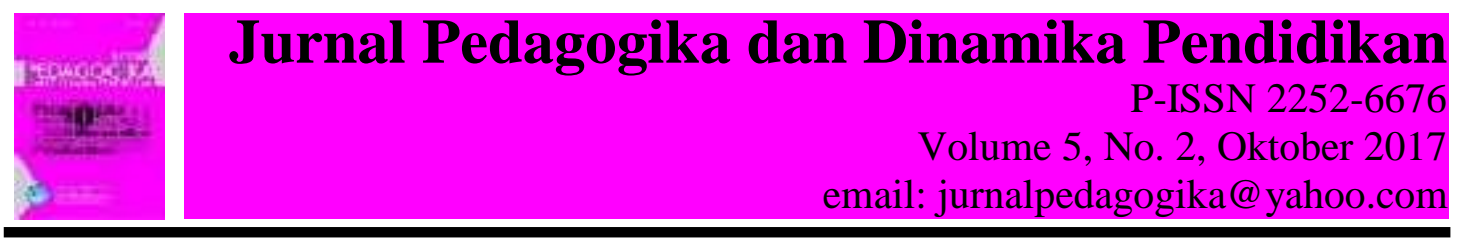

\title{
PENGARUH LINGKUNGAN SEBAGAI SUMBER BELAJAR TERHADAP HASIL BELAJAR GEOGRAFI DI SMA 1 PIRU KABUPATEN SERAM BAGIAN BARAT
}

\author{
Susan Evelin Manakane \\ Dosen Program Studi Pendidikan Geografi FKIP Universitas Pattimura \\ email: uchanmanakane@ rocketmail.com
}

\begin{tabular}{l}
\hline ARTICLE INFO \\
\hline Article History: \\
Accepted 13 September 2017 \\
Available online 23 Oktober 2017 \\
\hline
\end{tabular}

Keywords:

Lingkungan, Sumber Belajar, Hasil Belajar.

\begin{abstract}
Kondisi empiris guru masih menggunakan buku paket sebagai sumber belajar utama dan terpaku pada pembelajaran di dalam kelas yang bersifat monoton padahal potensi lingkungan yang ada dapat dijadikan sebagai media dan sumber pembelajaran yang dapat menstimulun proses berfikir peserta didik untuk lebih kreatif dan kritis Sehingga salah satu cara yang dapat digunakan untuk meningkatkan kemampuan kecerdasan keruangan seperti menentukan lokasi, jarak dan lain sebagainya. Sehinga yang menjadi masalah dalam penelitian ini adalah adalah dengan memanfaatkan lingkungan laut sebagai sumber pembelajaran dapat meningkatkan hasil tes peserta didik pada kelas eksperimen yang menggunakan metode karya wisata. Apakah terdapat perbedaan hasil belajar antara peserta didik pada kelas eksperimen yang menggunakan metode karya wisata dengan peserta didik kelas kontrol yang menggunakan metode penugasan. Penelitian ini merupakan sebuah penelitian eksperimen dengan menggunakan Nonequivalent (Pretest and posttest) control group design Adapun pemilihan kelas yang kemudian dijadikan sebagai kelas eksperimen dan kelas kontrol yaitu berdasarkan nilai capaian ketuntasan belajar mengajar. Hasil penelitian menunjukkan bahwa nilai rata-rata peserta didik kelas eksperimen dengan menggunakan lingkungan sebagai sumber belajar dengan metode karya wisata untuk konsep keruangan $(86,8)$, hasil belajar $(5,5)$ sangat berbeda, sehingga dapat dikatakan bahwa kedua metode karya wisata dengan menggunakan lingkungan sebegai sumber belajar dapat digunakan sebagai alat untuk mengembangkan konsep keruangan, hasil test, hasil belajar peserta didik. Seluruh indikator konsep keruangan, hasil test dan hasil belajar mengalami peningkatan yang signifikan, namun baik pada kelas eksperimen konsep yang dapat dikembangkan adalah konsep lokasi, konsep tempat dan konsep hubungan timbal balik.
\end{abstract}




\section{PENDAHULUAN}

Lahirnya Undang-Undang No 20 Tahun 2003 tentang sistem pendidikan Nasional, berimplikasi pada kebijakan dalam hal pelaksanaan sistem pengelolaan pendidikan dari yang dikembangkan berdasarkan prinsip diverifikasi sesuai dengan satuan pendidikan dan potensi daerah. Maka setiap guru di sekolah harus mampu menjabarkan kurikulum secara kreatif dan inovatif kedalam sistem pembelajaran sesuai dengan karakteristik peserta didik dan kondisi daerah setempat. Adapun tujuan pembelajaran ilmu-ilmu sosial menurut Hasan (1996: 97) adalah mengembangkan kemampuan peserta didik dalam menguasai disiplin ilmu-ilmu sosial dan untuk mencapai tujuan pendidikan yang lebih tinggi. Oleh karena itu maka pembelajaran ilmu-ilmu sosial yang salah satunya adalah mata pelajaran geografi juga harus di desain sebaik mungkin dan secara keilmuan untuk pencapaian tujuan yang lebih tinggi atau tujuan yang maksimal terhadap setiap bidang ilmu, bukan hanya pencapaian terhadap tujuan pembelajaran yang di buat pada saat guru ke kelas, tetapi juga dapat memberikan kontribusi terhadap peserta didik ketika peserta didik selesai mengikuti proses pembalajaran di dalam kelas.

Menurut Muhibbun (2008: 132) secara global, faktor-faktor yang dapat mempengaruhi belajar peserta didik dapat di bedakan atas 3 macam yaitu : (1) Faktor Internal. (2) Faktor Eksternal. (3) Faktor Pendekatan Belajar (approach to leraning). Ketiga faktor di atas berkaitan satu dengan yang lain. Menurut Maryani (2007:931), saat ini di persekolahan ilmu geografi sering dianggap tidak menarik untuk dipelajari. Hal ini di sebabkan oleh beberapa faktor : (1) Pelajaran geografi sering terjebak dalam aspek kognitif tingkat rendah yaitu menghafal nama-nama tempat, sungai dan gunung atau sejumlah fakta yang lainnya.(2) Ilmu geografi seringkali dikaitkan dengan ilmu yang hanya pembuatan peta, (3) Geografi hanya menggambarkan tentang perjalanan-perjalanan manusia di permukaan bumi. (4) Proses pembelajaran ilmu geografi cenderung bersifat verbal, kurang melibatkan fakta-fakta aktual, tidak menggunakan media kongkrit dan teknologi mutahir. (5) Kurang aplikabel dalam memecahkan masalah-masalah yang berkembang saat ini.

Termasuk di dalamanya di desa Piru Seram Bagian Barat (SBB) yang dikenal dengan daerah pesisir karena potensi laut yang dimanfaatkan sebagai mata pencaharian utama bagi masyarakat, yang kesemuanya dapat dijadikan sebagai sumber balajar dalam aktivitas pembelajaran bagi peserta didik, sehingga membawa peserta didik pada pembelajaran yang lebih kongkrit dan akan selalau di ingat oleh peserta didik. Kondisi faktual yang masih terjadi di dalam proses pembelajaran pada bidang studi geografi di SMA kebanyakan guru masih menggunakan buku paket sebagai sumber belajar utama bagi peserta didik di dalam proses pembelajaran dan terpaku pada pembelajaran di dalam kelas yang bersifat monoton, disamping itu 
pembelajaran yang dilakukan tidak melatih peserta didik untuk berfikir kritis dalam memecahkan masalah-masalah kongkrit dan aktual yang berhubungan dengan materi pelajaran, sehingga tidak mengajarkan peserta didik untuk berfikir secara kritis dalam memecahkan masalah yang ada, dan juga tidak mengembangkan konsep keruangan yang ada dan harus dimiliki oleh peserta didik padahal potensi lingkungan yang ada dapat dijadikan sebagai sumber belajar yang dapat menstimulun proses berfikir peserta didik untuk lebih kreatif dan kritis dan juga dapat mengembangkan konsep keruangan yang merupakan bekal untuk peserta didik sebagai generasi muda penerus masa depan. Karena dengan pemahaman konsep keruangan yang ada pada peserta didik, maka terbentuk maeinset peserta didik tentang pentingnya mencintai lingkungan dan melestarikan lingkungan yang merupakan peserta didik tersebut berinteraksi dan hidup dan yang paling penting adalah tidak menggulanggi berbagai kesalahan generasi terdahulu dalam pengelolaan dan pemanfaatan tata ruang sekitar.

Adapun tujuan dari penelitian ini adalah mengetahui hasil tes peserta didik dengan memanfaatkan lingkungan laut sebagai sumber pembalajaran pada kelas eksperimen yang menggunakan metode karya wisata, mengetahui hasil tes peserta didik dengan memanfaatkan gambar lingkungan laut sebagai sumber belajar pada kelas kontrol yang menggunakan metode penugasan, Mengetahui hasil belajar pada peserta didik kelas eksperimen yang mengunakan metode karya wisata dengan peserta didik kelas kontrol yang menggunakan metode penugasan.

Berdasarkan uraian di atas maka dibuat hipotesis :

1. $\mathrm{H}_{\mathrm{a}}$ : Penggunaan lingkungan laut sebagai sumber belajar dapat meningkatkan hasi tes pada kelas yang menggunakan metode karya wisata

$\mathrm{H}_{0}$ : Pengunaan lingkungan laut sebagai sumber belajar tidak dapat meningkatkan hasil tes pada kelas yang menggunakan metode karya wisata

2. $\mathrm{H}_{\mathrm{a}}$ : Penggunaan lingkungan laut sebagai sumber belajar dapat meningkatkan hasil tes pada kelas yang menggunakan metode penugasan

$\mathrm{H}_{0}$ : Penggunaan lingkungan laut sebagai sumber belajar tidak dapat meningkatkan hasil tes pada kelas yang menggunukan metode penugasan

3. $\mathrm{H}_{\mathrm{a}}$ : Terdapat perbedaan hasil belajar pada kelas yang menggunakan metode karya wisata dan yang menggunakan metode penugasan.

$\mathrm{H}_{0}$ : Tidak Terdapat perbedaan hasil belajar pada kelas yang menggunakan metode karya wisata dan yang menggunakan metode penugasan.

\section{METODE PENELITIAN}

Metode penelitian yang digunakan dalam penelitian ini adalah metode kuantitatif dengan pendekatan eksperimen semu (Quasi experimental research) dengan disain 
Nonequivalent (Pretest and posttest) control group design. Desain Nonequivalent (Pretest and posttest) control group design menurut Creswell (Marzuki 1994:69), kelompok eksperimen A dan kelompok kontrol B diseleksi tanpa penetapan secara random. Kedua kelompok memperoleh pretest dan post test, dan hanya kelompok eksperimen yang menerima perlakuan. Dalam bidang pendidikan, suatu eksperimen dimaksudkan untuk menilai pengaruh suatu tindakan pendidikan terhadap tingkah laku atau menguji hipotesis tentang ada tidaknya pengaruh penggunaan lingkungan sebagai sumber belajar terhadap hasil belajar agar peserta didik dapat mengelola segala potensi laut yang ada didaerah setempat.

Tabel I Disain Penelitian

\begin{tabular}{|l|c|c|c|}
\hline \multicolumn{1}{|c|}{ Kelas } & Pretest & Perlakuan & Pos test \\
\hline Eksperimen ( A ) & $\mathrm{O}_{1}$ & $\mathrm{X}_{1}$ & $\mathrm{O}_{2}$ \\
\hline Kontrol ( B ) & $\mathrm{O}_{1}$ & $\mathrm{X}_{2}$ & $\mathrm{O}_{2}$ \\
\hline
\end{tabular}

Sumber : Creswall (Marzuki 1994:69)

\section{Keterangan:}

$\mathrm{O}_{1}=$ Tes awal pada kelompok eksperimen dan kelompok kontrol

$\mathrm{O}_{2}=$ Tes akhir pada kelompok eksperimen dan kelompok kontrol

$\mathrm{X}_{1}=$ Perlakuan menggunakan metode karya wisata

$\mathrm{X}_{2}=$ Perlakuan menggunakan metode penugasan

\section{Populasi dan Sampel Penelitian}

1. Populasi Penelitian

Menurut Sugiyono (2008:17) populasi adalah wilayah generalisasi yang terdiri atas objek/subjek yang mempunyai kualitas dan karakteristik tertentu yang ditetepkan oleh peneliti untuk dipelajari dan kemudian ditarik kesimpulan. Maka yang menjadi populasi dalam penelitian ini adalah peserta didik dan peserta didik kelas XI jurusan IPS pada SMA Negeri Seram Bagian Barat yang terdiri dari tiga (3) kelas, yakni kelas XIa, XIb. Dan XIc

2. Sampel Penelitian

Dalam penelitian sampel yang digunakan berdasarkan populasi yang teridiri dari 3 kelas yakni Kelas XIA, XIB,dan XIC di ambil kelas XIB dan XIC karena berdasarkan atas besarnya ketuntasan belajar yang di tetapkan oleh guru mata pelajaran geografi yaitu ketuntasan belajar mengajar pada kelas XI adalah 75 dan nilai capaian SKM pada tiap kelas berbeda yakni pada kelas XIa 70, kelas XIB 69 dan kelas XIC 68 yang masing-masing kelas berjumlah 31 orang siswa.

\section{Instrumen Penelitian}

Berdasarkan penjelasan di atas maka, instrument yang dipakai dalam penelitian ini adalah : 
1. Tes. Menurut Arikunto (2008: 36) tes adalah suatu alat atau prosedur yang sistematis dan objektif untuk memperoleh data-data atau keterangan-keterangan yang diinginkan tentang seseorang, dengan cara yang diperoleh yang boleh dikatakan tepat dan tepat

2. Lembaran Observasi. Menurut Arikunto (2008: 30) adalah suatu teknik yang dilakukan dengan cara mengadakan pengamatan secara teliti serta pencatatan secara sistematis. Observasi yang dilakukan adalah faktor yang diamati sudah didaftar secara sistematis dan sudah diurut kategorinya. Lembaran observasi di maksudkan untuk mengetahui pengunaan lingkungan laut sebagai sumber belajar. Yang kemudian akan dilaporkan dalam bentuk laporan dan dipresentasikan di depan kelas

3. Kuesioner. Menurut Arikunto (2008: 28) adalah sebuah daftar pertanyaan yang harus di isi oleh responden yang akan diukur (responden). Kuesioner yang disusun dengan menyediakan jawaban lengkap sehingga pengisi hanya memberi tanda pada jawaban yang dipilihnya. Kuesioner ini untuk mencari tentang pengembangan konsep keruangan.

4. Wawancara. Menurut Arikunto (2008: 37) adalah suatu metode atau cara yang digunakan untuk mendapatkan jawaban dari responden dengan jalan Tanyajawab sepihak. Wawancara dipakai untuk melihat aktiviatas kegiatan pembelajaran dengan menggunakan lingkungan sebagai sumber belajar dalam pengembangan konsep keruangan dan hasil belajar.

\section{Proses Pengembangan Instrumen}

Dalam penelitian kuantitatif analisis data menurut Sugiyono (2008: 207) adalah kegiatan setelah data dari seluruh responden atau sumber data lain terkumpul. Kegiatan dari analisis data adalah mengelompokan data berdasarkan variabel dan jenis responden, mentabulasi data berdasarkan variabel dari seluruh responden, menyajikan data tiap variabel yang diteliti, melakukan perhitungan untuk menjawab rumusan masalah, dan melakukan perhitungan untuk menguji hipotesis yang diajukan. Dimana dalam penelitian ini peneliti menggunakan bantuan program Anates $\mathrm{V}_{4}$.

1. Analisis Butir Soal (Item Analysis).

2. Menentukan Daya Pembeda.

3. Menentukan Reliabiltas.

\section{Teknik Analisa Data Statistik}

Setelah data terkumpul dari hasil penelitian, selanjutnya dilakukan analisis data yang bertujuan untuk menjawab hipotesa yang diajukan dalam penelitian dengan 
menggunakan cara analisa statistika. Namun dalam penelitian ini peneliti memakai program SPSS 16.

1. Menguji Normalitas

2. Menguji Homogenitas

3. Menguji Hipotesis

\section{HASIL PENELITIAN}

Pada uraian ini akan dibahas hasil penelitian dan pembahasan yang didasarkan pada tujuan penelitian yang telah dibuat pada penjelasan sebelumnya. Data penelitian di peroleh dari hasil observasi, hasil wawancara, hasil analisa kuesioner dan hasil tes yakni hasil pre test dan post-test baik pada kelas yang dijadikan sebagai kelas eksperimen dan kelas yang dijadikan sebagai kelas kontrol.

Data observasi di dapat dengan melihat proses pembelajaran yang dilakukan pada kelas kontrol maupun kelas eksperimen di SMA Negeri Seram Bagian Barat. Hasil wawancara untuk melihat tentang pengunaan lingkungan laut oleh masyarakat yang berkaitan dengan proses pembelajaran. Analisa kuesiner untuk melihat lingkungan

terhadap pengembangan konsep keruangan, sedangkan hasil belajar diperoleh dengan melihat hasil pre-test dan post-test pada kelas kontrol maupun kelas eksperimen untuk melihat ada tidaknya perkembangan dalam proses pembelajaran yang dibuat dalam hasil belajar atau nilai. Adapun hasil temuan pada lokasi penelitian adalah sebagai berikut.

\section{Hasil Penelitian}

\section{Penguasaan Materi Awal Kelas Kontrol}

Data Pre-test peserta didik pada kelas kontrol diperoleh juga dari hasil test sebelum di adakan kegiatan proses belajar mengajar untuk mengetahui

pemahaman awal peserta didik terhadap materi yang di ajarkan oleh peserta didik dengan menggunakan lingkungan laut sebagai sumber belajar dengan metode penugasan. Adapun data pre-test pada kelompok kontrol yang dilakukan pada kelas XIC. Uraian penskoran nilai hasil pre-test pada kelas eksperimen dapat dilihat pada gambar 4.4 di bawah ini :

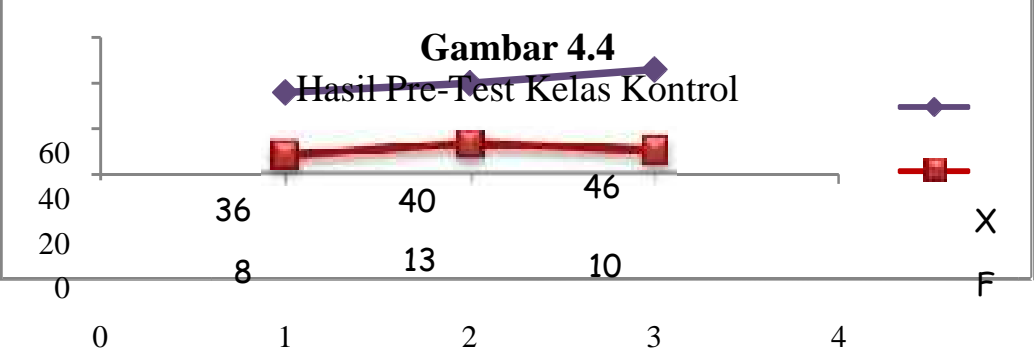

Sumber : Hasil Penelitian 2010 
Berdasarkan gambar 4.4 dapat disimpulkan bahwa terdapat penyebaran skor hasil test pada kelas kontrol menggunakan lingkungan laut sebagai sumber belajar dengan metode penugasan. Data pre-test pada kelas kontrol terdapat kisaran skor pre-test dari 36 sebanyak 8 orang peserta didik atau sebesar $26 \%$, skor pre-test dari 40 sebanyak 13 orang peserta didik atau sebesar $42 \%$ dan skor pre-test 46 sebanyak 10 orang peserta didik atau sebesar $32 \%$. Dengan nilai rata-rata adalah pada kelas kontrol yang menggunakan lingkungan sebagai sumber belajar sebesar dengan metode penugasan adalah 41. Hasil pre-test pada kelas kontrol tidak berbeda jauh dengan kelas ekperimen.

\section{Penguasaan Materi Akhir Kelas Kontrol}

Data post-test pada kelas kontrol di uraikan pada gambar 4.5 di bawah ini.

Gambar ini menjelaskan tentang hasil test pada kelas kontrol dimana, pada kelas kontrol dalam proses pembelajaran mengalamai sedikit peningkatan dari skor pre-test pada kelas kontrol. walaupun peningkatan yang terjadi pada kelas kontrol tidaklah sebanding dengan peningkatan yang terjadi pada kelas ekperimen.

Berikut ini hasil test dari kelas kontrol yang diuraikan pada gambar 4.10.

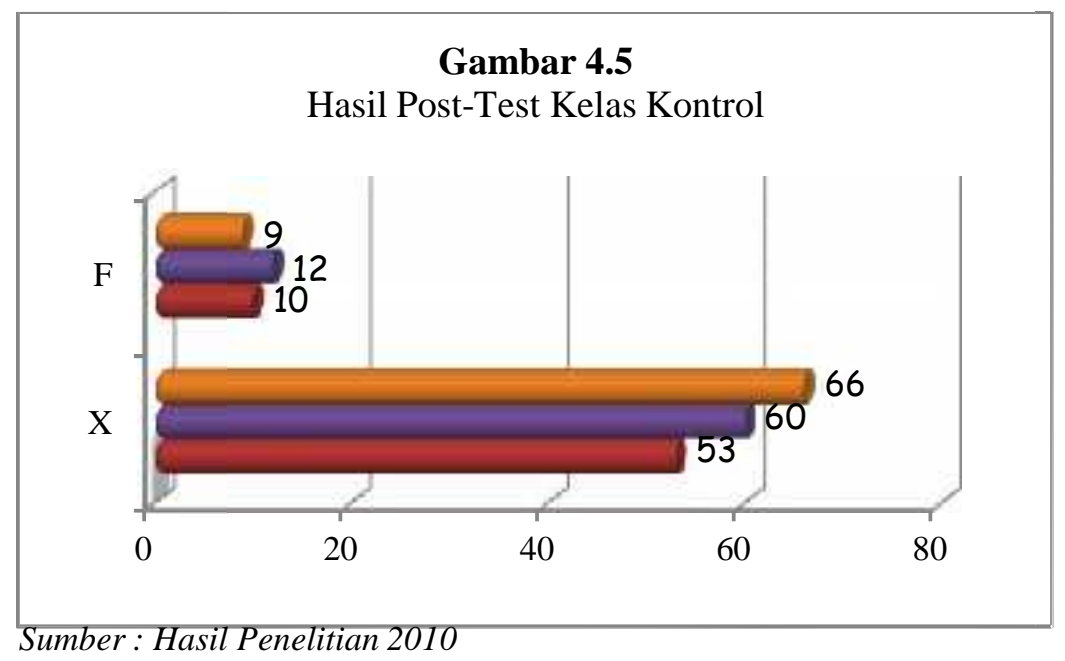

Rata-rata hasil belajar yang di peroleh pada kelas kontrol setelah pembelajaran adalah 59. dari gambar 4.10 dapat disimpulkan bahwa pada kelas kontrol hasil test yang diperoleh terdiri dari nilai 53 sebanyak 10 orang peserta didik atau

sebanyak 30\%, nilai 60 sebanyak 12 orang peserta didik atau sebanyak 33\% dan nilai 9 sebanyak 9 atau sebanyak 37\%. Berikut pada gambar 4.11 akan digambarkan perbedaan antara pre-test dan post test pada kelas kontrol yang menggunakan lingkungan sebagai sumber belajar dengan metode penugasan. 


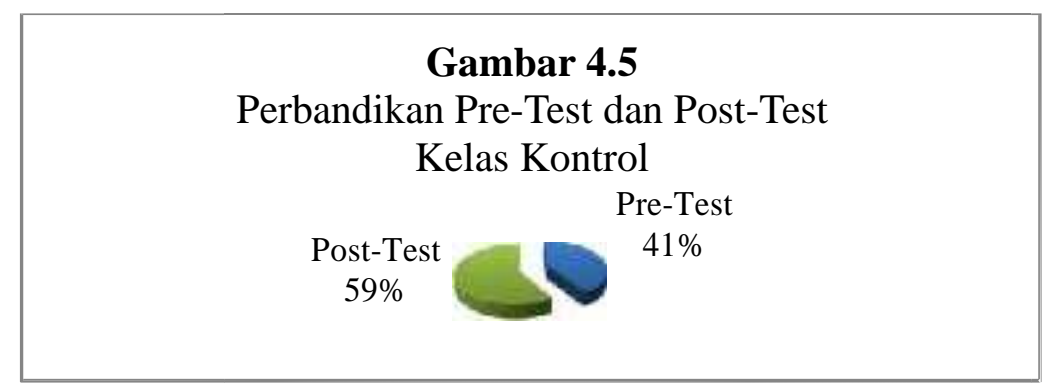

Sumber : Hasil Penelitian 2010

Berdasarkan gambar 4.5 dapat disimpulkan bahwa, terdapat perbedaan antara hasil test pre-test dan post-test pada kelas kontrol. Selisih antara pre-test dan post pada kelas kontrol sebesar 18 dan peningkatan yang terjadi pada kelas kontrol tidak menunjukan peningkatan yang signifikan. Hal ini dapat disimpulkan karena suasana dari kegiatan belajar mengajar yang terjadi di dalam kelas kontrol sangat berbeda dengan kegiatan belajar mengajar di kelas eksperimen. Pada kelas

kontrol peserta didik tidak semuanya aktif, dan juga ada perbedaan sikap yang sangat menonjol pada kegiatan pembelajaran di kelas kontrol yaitu pada kelas kontrol peserta didik hanya terpaku pada gambar yang diberikan oleh guru dan juga berdasarkan berbagai literatur yang dipakai oleh masing-masing kelompok sedangakan pada kelas eksperimen peserta didik begitu aktif dan kritis dalam

kegiatan diskusi dan pada saat peserta didik menerima penjelasan atau penguatan konsep yang dilakukan oleh guru sehingga membuat gurupun sedikit kewalahan dalam hal menjawab berbagai pertanyaan yang diajukan oleh peserta didik.

\section{Hasil Belajar Kelas Eksperimen dan Kelas Kontrol Kelas Eksperimen}

Data hasil belajar peserta didik pada kelas eksperimen diperoleh dari hasil test, penguasaan konsep dan tugas yang dikerjakan oleh para peserta didik. Adapun data hasil belajar pada kelas XIB yang dijadikan sebagai kelas eksperimen. Uraian hasil belajar pada kelas eksperimen dapat dilihat pada gambar 4.6 di bawah ini : 


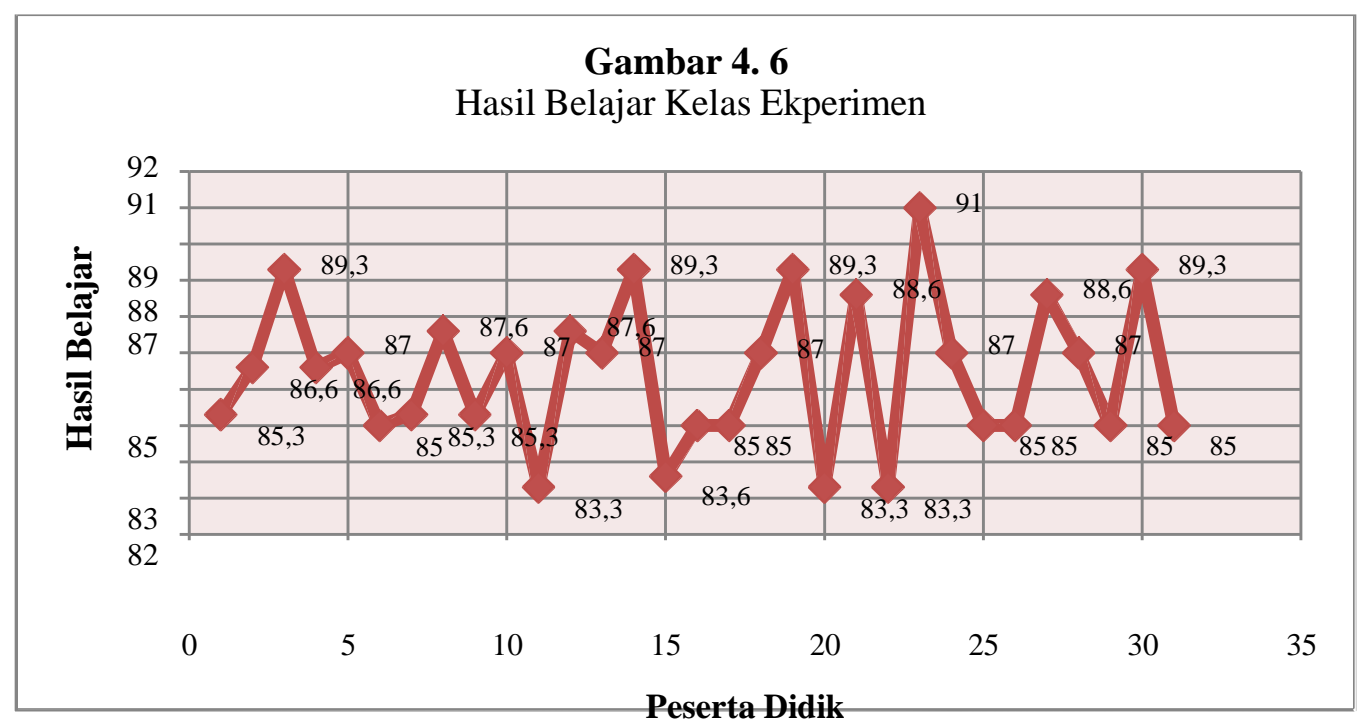

Sumber: Hasil Penelitian 2010

Berdasarkan gambar 4.6 dapat disimpulkan bahwa, hasil belajar yang dicapai dengan menggunakan lingkungan laut, tidak hanya dapat meningkatkan pemahaman konsep, hasil tes tatapi, juga dapat meningkatkan hasil belajar pada kelas ekperimen yang menggunakan lingkungan laut sebagai sumber belajar dengan metode karya wisata. Persebaran nilai hasil belajar peserta didik sangat bervariasai, berkisar dari nilai 80 sampai 91. Selain itu, dengan menggunakan lingkungan laut sebagai sumber belajar lebih dapat melatih dan menstimulus para peserta didik untuk lebih aktif, lebih kritis dalam proses belajar mengajar karena para peserta didik beronteraksi langsung dengan lingkungan tempat terjadi berbagai fenomena alam dan sosial yang terjadi pada lingkungan sekitar pantai waemeteng. Selain itu peserta didik juga mengetahui berbagai informasi berbagai aktifitas ekomoni masyarakat, yang mendiami daerah sekitar pantai waemeteng, bagaimana pengelolaan hasil laut yang dilakukan oleh masyarakat pantai waementeng dan juga harapan, kendala serta masalah-masalah yang dihadapai oleh masyarakat sekitar pantai waemeteng.

Berdasarkan gambar 4.7 dapat diketahui nilai rata-rata dari hasil belajar pada kelas eksperimen yang menggunakan lingkungan pantai waemeteng sebagai sumber belajar adalah 8,6 dengan presentasi sebesar $61 \%$ hal ini sangat berbeda pada hasil belajar kelas kontrol.

\section{Hasil Belajar Kelas Kontrol}

Hasil belajar kelas kontrol juga diperoleh dari hasil pengitungan semua nilai yang didapat dalam kegiatan proses belajar mengajar peserta didik. Pada kelas kontrol menggunakan lingkungan sebagai sumber belajar dengan metode penugasan. Berikut 
akan diuraikan pada gambar 4.7 tentang persebaran nilai masing-masing peserta didik pada kelas kontrol

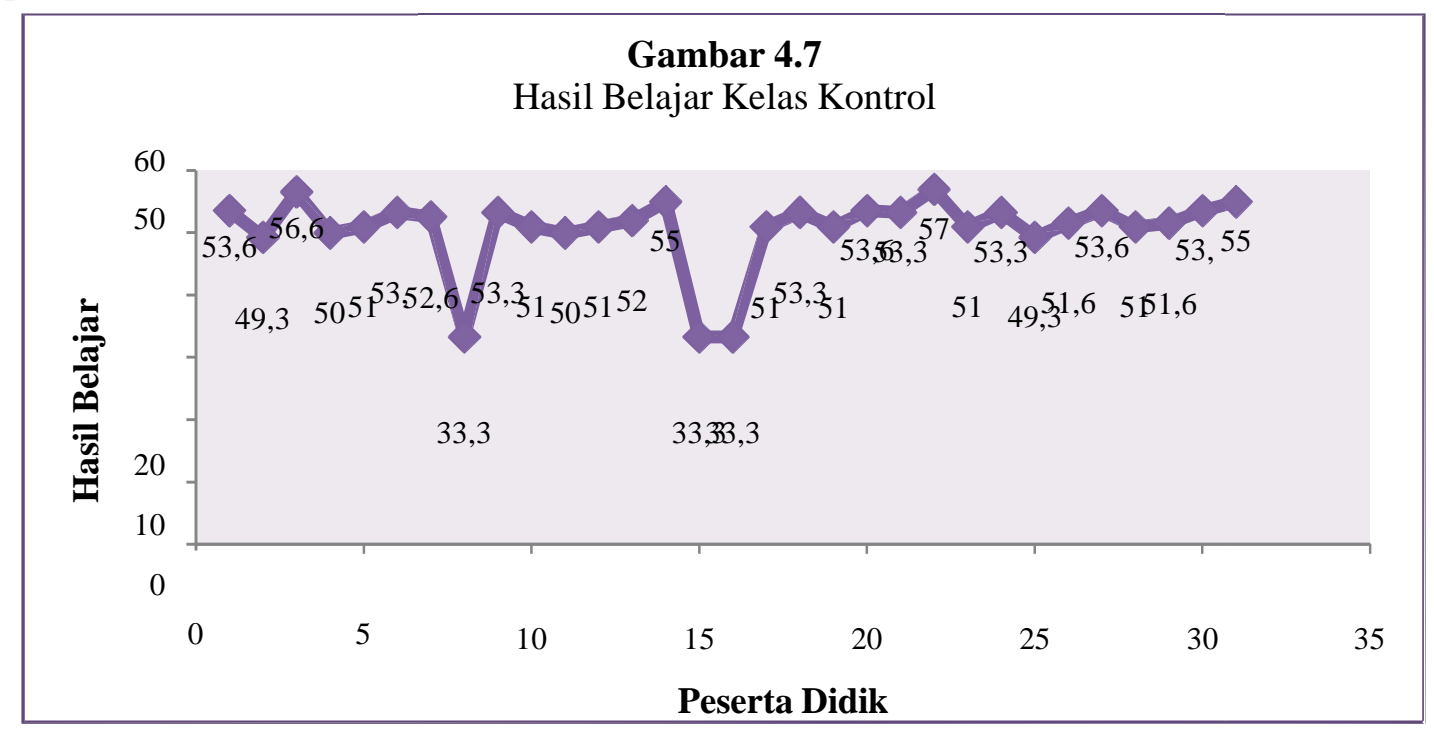

Sumber : Hasil Penelitian 2010

Berdasarkan gambar 4.7 dapat di simpulkan bahwa persebaran nilai hasil belajar pada kelas kontrol yang menggunakan metode penugasan berkisar pada nilai 30 sampai dengan nilai 60, dengan nilai rata-rata 5,5 atau sebesar 39\%, hal ini sangat berbeda pada kelas eksperimen yang menggunakan metode karya wisata.

Pada kelas kontrol, hanya beberapa peserta didik yang aktif dalam kegiatan

belajar mengajar. Hal ini karena peserta didik tidak dilatih dan dikenalkan tentang lingkungan tempat peserta didik tersebut berinteraksi, sehingga pembelajaran hanya bersifat hapalan. Berikut pada gambar 4.8 akan diuraikan perbadingan hasil belajar pada kelas ekperimen dan kelas kontrol.

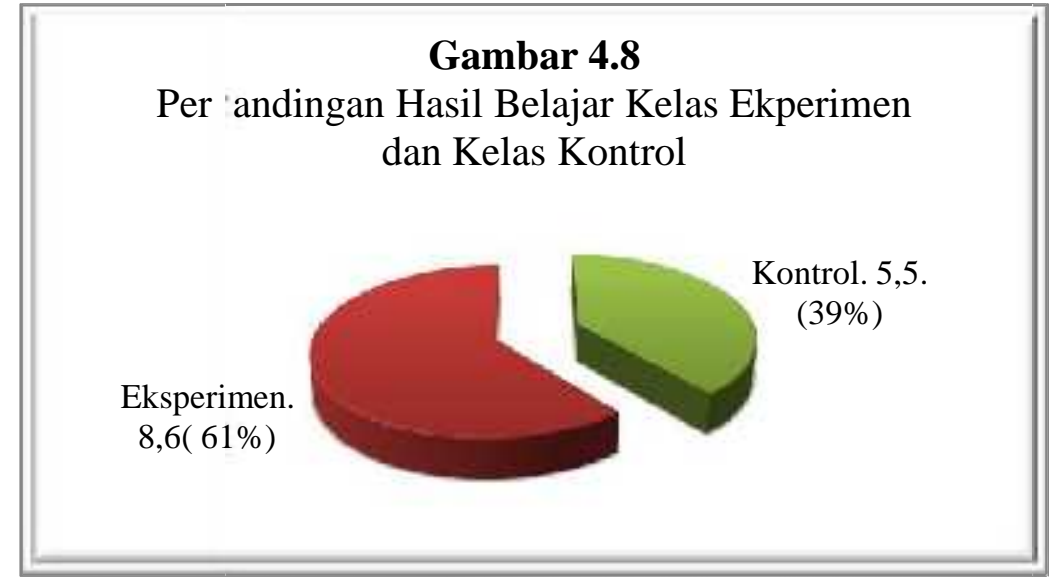

Sumber : Hasil Penelitian 2010 
Berdasarkan gambar 4.8 dapat disimpulkan terdapat perbedaan hasil belajar pada kelas ekperimen yang menggunakan lingkungan sebagai sumber belajar dengan metode karya wisata dan kelas kontrol yang menggunakan metode penugasan.

\section{Uji Hipotesis Metode Karya Wisata}

Berikut ini adalah hasil penguraian mengujian hipotesis ke dua yaitu untuk mengetahui apakah dengan menggunakan lingkungan sebagai sumber belajar dengan menggunakan metode karya wisata dapat meningkatkan hasil test, hasil perhitungan dapat dilihat pada tabel 4.2 di bawah ini :

Tabel 4.2

One-Sample Statistics Metode Karya Wisata

\begin{tabular}{|l|r|r|r|r|}
\hline & $\mathrm{N}$ & \multicolumn{1}{|c|}{ Mean } & Std. Deviation & \multicolumn{1}{c|}{$\begin{array}{c}\text { Std. Error } \\
\text { Mean }\end{array}$} \\
\hline PreTest & 31 & 39.4839 & 3.72264 & .66861 \\
PostTest & 31 & 85.2581 & 5.02638 & .90276 \\
\hline
\end{tabular}

Sumber : Hasil Analisis SPSS

Berdasarkan uraian tabel output deskritif statistik nilai pre-test dan post-test pada kelas eksperimen mempunyai nilai $\mathrm{N}$ atau banyaknya sampel yang diteliti pada kelas eksperimen sebanyak 31 dengan Mean atau rata-rata hitung sebesar 39, 4839 pada nilai Pre-Test dan 85, 2581 pada nilai post test, Standar Deviation atau perbedaan skor rata-rata antara pre-test adalah 3, 72264 dan post-test adalah 5, 02638. Standar Error Mean atau kesalahan pengukuran rata-rata sebesar pada nilai pre-test adalah 0, 66861 dan nilai post-test adalah 0, 90276. Sebelum dilakukan pengujian terhadap apakah lingkungan dapat meningkatkan hasil test dibuat suatu hipotesis. Maka di buat suatu hipotesis yaitu :

$\mathrm{H}_{\mathrm{a}}$ : Penggunaan lingkungan laut sebagai sumber belajar dapat meningkatkan hasil tes pada kelas yang menggunakan metode karya wisata.

$\mathrm{H}_{0}$ : Pengunaan lingkungan laut sebagai sumber belajar tidak dapat meningkatkan hasil tes pada kelas yang menggunakan metode karya wisata.

Berikut ini hasil pengujian hipotesis yang dapat dilihat pada tabel 4.2 dengan menggunakan program SPSS di bawah ini : 
Tabel 4.3

One-Sample Test Metode Karya Wisata

\begin{tabular}{|c|c|c|c|c|c|c|}
\hline & \multicolumn{6}{|c|}{ Test Value $=0$} \\
\hline & \multirow[b]{2}{*}{$\mathrm{T}$} & \multirow[b]{2}{*}{ Df } & \multirow{2}{*}{$\begin{array}{l}\text { Sig. (2- } \\
\text { tailed) }\end{array}$} & \multirow{2}{*}{$\begin{array}{c}\text { Mean } \\
\text { Difference }\end{array}$} & \multicolumn{2}{|c|}{$\begin{array}{l}\text { 95\% Confidence } \\
\text { Interval of the } \\
\text { Difference }\end{array}$} \\
\hline & & & & & Lower & Upper \\
\hline PreTest & 59.054 & 30 & .000 & 39.48387 & 38.1184 & 40.8493 \\
\hline PostTest & 94.441 & 30 & .000 & 85.25806 & 83.4144 & 87.1018 \\
\hline
\end{tabular}

Berdasarkan hasil analisis dari tabel 4.3 dapat disimpulkan bahwa :

a. Siq 2 adalah signifikansi dua sisi, pada tabel besarnya sig 2 adalah 0,000 .

b. Mean defference adalah perbandingan rata-rata pada kelompok pretest - rata-rata post test. Pada metode karya wisata nilai pre-test adalah 39, 48387 dan nilai post test adalah 85, 25806.

c. $\quad 95 \%$ adalah selang kepercayaan. Nilai lower dibanding nilai upper. Nilai upper lebih tinggi dari nilai lower artinya keyakinan persamaan varian berada pada tingkat kepercayaan $95 \%$ untuk menguji hipotesis penguasaan materi sebelum pengajaran menggunakan t-test untuk varian yang sama.

d. Df adalah derajat kebebasan atau degree of freedom dengan rumus.

$$
\begin{aligned}
\text { Df } & =(\mathrm{N} 1-1) \\
& =31-1 \\
& =30
\end{aligned}
$$

Dengan df sebesar 30 akan dibandingkan dengan nilai $t_{\text {tabel }}$ pada taraf signifikan $5 \%$ maupun pada taraf signifikansi $1 \%$. Ternyata dengan df sebesar 30 diperoleh harga kritik $\mathrm{t}$ atau $\mathrm{t}_{\text {tabel }}$ pada taraf signifikansi $5 \%$ sebesar 2, 04, sedangkan taraf signifikansi $1 \% \mathrm{t}_{\text {tabel }}$ sebesar 2, 75. Dengan membandingkan besarnya $\mathrm{t}$ yang kita peroleh pada nilai post test dalam penghitungan adalah $\left(t_{o}=94.441\right)$ dan besarnya $t$ yang tercantum pada nilai $\mathrm{t}\left(\mathrm{t}_{\mathrm{t}} \cdot \mathrm{t}_{\mathrm{s}} 5 \%=2,04\right.$ dan $\mathrm{t}_{\mathrm{t}} \cdot \mathrm{t}_{\mathrm{s}} 1 \%=2,75$ maka dapat diketahui bahwa $\mathrm{t}_{\mathrm{o}}>\mathrm{t}_{\text {tabel }}$ yaitu :

$$
2,04<94.441>2,75
$$

Karena $t_{\mathrm{o}}>\mathrm{t}_{\mathrm{t}}$ maka hipotesa nihil (Ho) yang diajukan di tolak, ini berarti bahwa adanya perbedaan skor hasil belajar dengan menggunakan lingkungan sebagai sumber belajar dengan motode karya wisata dapat meningkatkan hasil Test lebih baik yang berarti terjadi peningkatan hasil test yang sangat sangat meyakinkan (signifikan). 


\section{Uji Hipotesis Metode Penugasan}

Uji hipotesis ke tiga dilakukan untuk melihat pengunaan lingkungan sebagai sumber belajar dapat atau tidaknya meningktakan hasil tes pada kelas yang mengunakan metode penugasan. Berikut ini pada tabel 4.4 penguraian One-Sample Statistics pada Metode Penugasan.

Tabel 4.4

One-Sample Statistics Metode Penugasan

\begin{tabular}{|l|r|r|r|r|}
\hline & $\mathrm{N}$ & \multicolumn{1}{|c|}{ Mean } & Std. Deviation & $\begin{array}{c}\text { Std. Error } \\
\text { Mean }\end{array}$ \\
\hline PreTest & 31 & 39.4839 & 3.72264 & .66861 \\
PostTest & 31 & 59.4839 & 5.18248 & .93080 \\
\hline
\end{tabular}

Pada tabel 4.4 diuraikan hasil belajar pada metode penugasan pre-test mempunyai nilai yang sama banyaknya yaitu 31 dengan nilai Mean pada nilai pre-test adalah 39, 4839 dan pada nilai post-test adalah 59,4839. Nilai Standar Deviation pada kelas pre-test adalah 3, 72264 dan post-test adalah 5, 18248 dan Standar Error Mean pada kelompok pre-test adalah 0, 66861 dan pada kelompok post-test adalah 0 , 93080. Berikut ini hasil pengujian untuk menguji hipotesis yang berbunyi :

$\mathrm{H}_{\mathrm{a}}$ : Penggunaan lingkungan laut sebagai sumber belajar dapat meningkatkan hasil tes pada kelas yang menggunakan metode penugasan.

$\mathrm{H}_{0}$ : Penggunaan lingkungan laut sebagai sumber belajar tidak dapat meningkatkan hasil tes pada kelas yang menggunukan metode penugasan.

Berikut hasil penghitungannya dapat dilihat pada tabel 4.5 dibawah ini :

Tabel 4.5

One-Sample Test Metode Penugasan

\begin{tabular}{|c|c|c|c|c|c|c|}
\hline & \multicolumn{6}{|c|}{ Test Value $=0$} \\
\hline & \multirow[b]{2}{*}{$\mathrm{T}$} & \multirow[b]{2}{*}{ Df } & \multirow{2}{*}{$\begin{array}{l}\text { Sig. (2- } \\
\text { tailed) }\end{array}$} & \multirow{2}{*}{$\begin{array}{c}\text { Mean } \\
\text { Difference }\end{array}$} & \multicolumn{2}{|c|}{$\begin{array}{l}\text { 95\% Confidence } \\
\text { Interval of the } \\
\text { Difference }\end{array}$} \\
\hline & & & & & Lower & Upper \\
\hline PreTest & 59.054 & 30 & .000 & 39.48387 & 38.1184 & 40.8493 \\
\hline PostTest & 63.906 & 30 & .000 & 59.48387 & 57.5829 & 61.3848 \\
\hline
\end{tabular}

Sumber : Hasil Analisis SPSS 
Berdasarkan hasil perhitungan uji perbedaan rata-rata (uji-T), dapat di simpulkan:

a. Mean deffernce adalah perbandingan rata-rata nilai pre-test - rata-rata nilai posttest adalah 39, 48387 dan pada nilai pro-test adalah 59, 5829

b. $95 \%$ adalah selang kepercayaan. Nilai lower dibanding nilai upper. Nilai upper lebih tinggi dari nilai lower artinya keyakinan persamaan varian berada pada tingkat kepercayaan $95 \%$ untuk menguji hipotesis penguasaan materi sebelum pengajaran menggunakan t-test untuk varian yang sama.

c. Df adalah derajat kebebasan atau degree of freedom dengan rumus

$$
\begin{aligned}
\text { Df } & =(\mathrm{N} 1-1) \\
& =31-1 \\
& =30
\end{aligned}
$$

Dengan df sebesar 30 akan dibandingkan dengan nilai $t_{\text {tabel }}$ pada taraf signifikan $5 \%$ maupun pada taraf signifikansi $1 \%$. Ternyata dengan df sebesar 30 diperoleh harga kritik $\mathrm{t}$ atau $\mathrm{t}_{\text {tabel }}$ pada taraf signifikansi $5 \%$ sebesar 2, 04, sedangkan taraf signifikansi $1 \% \mathrm{t}_{\text {tabel }}$ sebesar 2, 75. Dengan membandingkan besarnya $\mathrm{t}$ yang kita peroleh pada dalam penghitungan adalah $\left(t_{o}=63,906\right)$ dan besarnya $t$ yang tercantum pada nilai $\mathrm{t}_{(} \mathrm{t}_{\mathrm{t}} \cdot \mathrm{t}_{\mathrm{s}} 5 \%=2,04$ dan $\mathrm{t}_{\mathrm{t}} \cdot \mathrm{t}_{\mathrm{s}} 1 \%=2,75$ maka dapat diketahui bahwa $\mathrm{t}_{\mathrm{o}}>\mathrm{t}_{\mathrm{t}}$ yaitu :

$$
2,04<63,906>2,75
$$

Karena $t_{o}>t_{t}$ maka hipotesa nihil (Ho) yang diajukan di tolak, ini berarti bahwa adanya perbedaan skor hasil belajar dengan menggunakan lingkungan sebagai sumber belajar dengan menggunakan metode penugasan merupakan perbedaan yang berarti atau perbedaan yang meyakinkan (signifikan) karena terjadi peningkatan hasil belajar, namun hasil yang diperoleh tidak seperti pada kelas yang mengunakan metode karya wisata.

\section{Hasil Belajar Metode Karya Wisata dan Metode Penugasan}

Setelah dilakukan uji hipotesis pada kelas eksperimen dan kelas kontrol kemudian dilakukan uji hipotesi untuk memgetahui apakah hasil test pada kelompok ekperimen lebih baik atau kelas kontrol. Pengujian perbedaan rata-rata dengan menggunakan uji statistik parametik yaitu uji-T dengan menggunakan program SPSS Versi 16. 00, yaitu independent - Sample T-test hasil perhitungannya dapat dilihat pada tabel 4.14 di bawah ini : 
Tabel 4.5

Group Statistics Perbandingan Hasil Belajar KW \& Penugasan

\begin{tabular}{|ll|r|r|r|r|}
\cline { 2 - 5 } & Kelas & \multicolumn{1}{|c|}{$\mathrm{N}$} & Mean & $\begin{array}{c}\text { Std. } \\
\text { Deviation }\end{array}$ & $\begin{array}{c}\text { Std. Error } \\
\text { Mean }\end{array}$ \\
\cline { 2 - 6 } Hasil Belajar & Eksperimen & 31 & 86.2258 & 2.01179 & .36133 \\
& Kontrol & 31 & 50.3226 & 6.05193 & 1.08696 \\
\hline
\end{tabular}

Sumber : Hasil Analisis SPSS

Berdasarkan uraian tabel 4.14 output deskritif statistik nilai pre-test pada kelas eksperimen mempunyai nilai $\mathrm{N}$ atau banyaknya sampel yang diteliti pada kelas eksperimen sebanyak 31 dengan Mean atau rata-rata hitung sebesar 86.2258, Standar Deviation atau perbedaan skor rata-rata antara kelas eksperimen dan rata-rata kelas kontrol sebesar 2.01179 dan Standar Error Mean atau kesalahan pengukuran rata-rata sebesar 0, 36133, sedangkan pada kelas kontrol nilai $\mathrm{N}$ atau banyaknya sampel yang diteliti pada kelas kontrol sebanyak 31 sama dengan kelas eksperimen, nilai Mean atau nilai rata-rata hitung sebesar 50.3226 dengan Standar deviation atau perbedaan Standar skor rata-rata 6.05193 dan Standar Error Mean atau kesalahan/kesesatan paengukuran rata-rata sebesar 1.08696. Untuk menguji hipotesis yang ke empat yang berbunyi :

$\mathrm{H}_{\mathrm{a}}$ : Pengunaan lingkungan laut sebagai sumber belajar dapat meningkatkan hasil belajar peserta didik.

$\mathrm{H}_{0}$ : Pengunaan lingkungan laut sebagai sumber belajar tidak dapat meningkatkan hasil belajar peserta didik.

Berikut hasil analisis uji t untuk menguji hipotesa di atas pada tabel 4.15 di bawah ini :

Tabel 4.15

Independent Samples Test

\begin{tabular}{|c|c|c|c|c|c|c|c|c|c|c|}
\hline & \multirow{2}{*}{\multicolumn{2}{|c|}{$\begin{array}{c}\text { Levene's Test } \\
\text { for Equality of } \\
\text { Variances } \\
\text { F }\end{array}$}} & \multirow[b]{2}{*}{$\mathrm{T}$} & \multirow[b]{2}{*}{ Df } & \multirow{2}{*}{$\begin{array}{l}\text { Sig. (2- } \\
\text { tailed) }\end{array}$} & \multirow{2}{*}{$\begin{array}{c}\text { Mean } \\
\text { Difference }\end{array}$} & \multirow{2}{*}{$\begin{array}{l}\text { Std. Error } \\
\text { Difference }\end{array}$} & \multicolumn{2}{|c|}{$\begin{array}{l}95 \% \text { Confidence } \\
\text { Interval of the } \\
\text { Difference }\end{array}$} \\
\hline & & & & & & & & & Lower & Upper \\
\hline $\begin{array}{l}\text { Hasil } \\
\text { Belajar }\end{array}$ & $\begin{array}{l}\text { Equal } \\
\text { variances } \\
\text { assumed }\end{array}$ & 4.588 & .036 & 31.344 & 60 & .000 & 35.90323 & 1.14544 & 33.61200 & 38.19445 \\
\hline & $\begin{array}{l}\text { Equal } \\
\text { variances not } \\
\text { assumed }\end{array}$ & & & 31.344 & 36.550 & .000 & 35.90323 & 1.14544 & 33.58138 & 38.22507 \\
\hline
\end{tabular}


Berdasarkan hasil perhitungan uji perbedaan rata-rata (uji-T), dapat di jelaskan :

a. Levene's adalah uji kesamaan varians. Dalam Levene's test terdapat dua data, yang pertama adalah equal variances assusmed (jika varians diasumsikan sama) dan data equal variences not assumed (jika varians diasumsikan tidak sama).

b. $F$ adalah distribusi $F$ hitung dibandingkan dengan $F$ tabel. Nilai f pada hasil belajar adalah 4.588

c. Siq 2 adalah signifikansi dua sisi, pada tabel besarnya sig 2 pada adalah 0.000

d. Mean defference adalah perbandingan rata-rata pada kelompok eksperimen rata-rata kelompok kontrol. Pada nilai Mean defference adalah 35.90323

e. Standar error difference adalah kesalahan pengukuran rata-rata. Pada nilai hasil belajar standar error diference adalah1.14544

f. $\quad 95 \%$ adalah selang kepercayaan. Nilai lower dibanding nilai upper. Nilai upper lebih tinggi dari nilai lower artinya keyakinan persamaan varian berada pada tingkat kepercayaan $95 \%$ untuk menguji hipotesis penguasaan materi sebelum pengajaran menggunakan t-test untuk varian yang sama.

g. Df adalah derajat kebebasan atau degree of freedom dengan rumus

$$
\begin{aligned}
\text { Df } & =(\mathrm{N} 1-1)+(\mathrm{N} 2-1) \\
& =(31-1)+(31-1) \\
& =60
\end{aligned}
$$

Dengan df sebesar 60 akan dibandingkan dengan nilai $t_{\text {tabel }}$ pada taraf signifikan $5 \%$ maupun pada taraf signifikansi $1 \%$. Ternyata dengan df sebesar 60 diperoleh harga kritik $\mathrm{t}$ atau $\mathrm{t}_{\text {tabel }}$ pada taraf signifikansi $5 \%$ sebesar 2, 00, sedangkan taraf signifikansi $1 \% \mathrm{t}_{\text {tabel }}$ sebesar 2, 65. Dengan membandingkan besarnya $\mathrm{t}$ yang kita peroleh pada nilai hasil belajar dalam penghitungan adalah $\left(\mathrm{t}_{\mathrm{o}}=31.344\right)$ dan besarnya $\mathrm{t}$ yang tercantum pada nilai $\mathrm{t}\left(\mathrm{t}_{\mathrm{t}} \cdot \mathrm{t}_{\mathrm{s}} 5 \%=2,00\right.$ dan $\mathrm{t}_{\mathrm{t}} \cdot \mathrm{t}_{\mathrm{s}} 1 \%=2,65$ maka dapat diketahui bahwa to adalah lebih besar dari $t_{\text {tabel }}$ yaitu :

$$
2,00<31.344>2,65
$$

Karena $t_{o}>t_{t}$ maka hipotesa nihil (Ho) yang diajukan di tolak, ini berarti bahwa adanya perbedaan skor hasil belajar dengan menggunakan lingkungan sebagai sumber belajar dengan motode karya wisata lebih baik daripada peserta didik yang belajar di dengan metode penugasan merupakan perbedaan yang berarti atau perbedaan yang meyakinkan (signifikan). Kesimpulan yang dapat kita tarik adalah berdasarkan hasil uji coba di atas, secara meyakinkan dapat dikatakan lingkungan sebagai sumber belajar dalam meningkatkan hasil tes, telah menujukan efektifitasnya yang nyata dalam arti kata dapat diandalakan sebagai sumber belajar yang baik untuk meningkatkan hasil belajar khusunya bidang studi geografi pada tingkat Sekolah Menengah Atas dengan materi pelestarian lingkungan hidup. 


\section{PEMBAHASAN}

Berdasarkan hasil penelitian dan analisis data yang diperoleh pada saat kegiatan pembelajaran, dimana sesunguhnya sesunguhnya aktivitas yang dilakukan oleh setiap orang termasuk di dalamnya adalah peserta didik adalah suatu kegitan belajar. hal ini memperkuat pendapat Aunurrahman (2009: 33) bahwa dalam kehidupan manusia sehari-hari hampir tidak pernah tidak dapat terlepas dari kegiatan belajar, baik ketika seseorang melaksanakan kegiatan sendiri, maupun dalam suatu bentuk kelompok tertentu. Menurut Aunirrahman (2009: 39) Ciri yang paling mendasar dari behaviorisme adalah bahwa perubahan tingkah laku yang terjadi adalah berdasarkan paradigma S-R (Stimulus Respons), yaitu suatu proses yang memberikan respons tertentu terhadap sesuatu yang datang dari luar. Hal ini dibuktikan pada saat penelitian terjadi perubahan perilaku ketika peserta didik yang menggunakan lingkungan sebagai sumber belajar dengan metode karya wisata distimulun dengan menggunakan lingkungan sebagai sumber belajar, apalagi lingkungan laut yang dipakai sesui dengan tujuan dan pencapain standar kompetensi yang ingin dicapai pada saat kegiatn pembelajaran itu dilakukan. Tetapi, dengan menggunakan lingkungan sebagai sumber belajar yang perlu di ingat oleh guru adalah dengan menggunakan lingkungan sebagai sumber belajar harus memperhatikan kesiapan guru dalam proses belajar yang akan dilakukan dan menyusun kegiatan belajar agar pembelajaran yang dilakukan dengan menggunakan lingkungan sebagai sumber belajar dengan metode karya wisata. hal ini memperkuat pendapat dari Ningrum (2009: 110) pendayagunaan lingkungan bagi kegiatan pembelajaran memerlukan ketrampilan guru dalam pemanfaatannya.

Namun perlu diyakini bahwa pemanfaatan lingkungan sebagai sumber belajar dapat menumbuhkembangkan kecintaan dan kepedulian peserta didik terhadap lingkungan. dan juga pendapat dari Sumaatmadja (1997: 112) stimulus berupa fakta, dari gejala dan masalah geografi secara terencana dan terarah dijadikan sarana untuk membangkitkan reaksi (Respons) sistem mental dan fisikal peserta didik. Dengan demikian, peserta didik akan peka terhadap kondisi permasalahan lingkungan yang menjadi dampak dari perilaku, tindakan dan perbuatan manusia terhadap lingkungan tadi.

\section{KESIMPULAN}

Berdasarkan hasil penelitian melalui proses pengelolaan analisis data dan uji hipotesisi dapat dibuat kesimpulan sebagai berikut:

1. Pembelajaran dengan mengunakan lingkungan sebagai sumber belajar pada kelas eksperimen yang menggunakan metode karya wisata dapat meningkatkan hasil test ini dilihat dari perolehan mean defference atau perbandingan rata-rata pada 
kelompok pretest - rata-rata post test. Pada metode karya wisata nilai pre-test adalah 39, 48387 dan nilai post test adalah 85, 25806 dan uji t dari pre-test pada kelas eksperimen adalah 59.054 dan post test adalah 94.441.

2. Pembelajaran dengan menggunakan lingkungan sebagai sumber belajar dengan metode pendekatan penugasan disebut sebagai kelas kontrol juga dapat meningkatkan hasil test walaupun tidak seperti yang terjadi pada kelas eksperimen ini diketahui dengan perolehan mean deffernce adalah perbandingan rata-rata nilai pre-test - rata-rata nilai post-test adalah 39,48387 dan pada nilai protest adalah 59, 5829. Dengan nilai uji t pre-test adalah 59.054 dan uji t post test adalah 63.906.

3. Pembelajaran menggunakan lingkungan sebagai sumber belajar kelas eksperimen dengan metode karya wisata dapat meningkatkan hasil belajar peserta didik dibandingkan dengan kelas kontrol dengan metode penugasan ini dilihat pada nilai $\mathrm{F}$ atau distribusi $\mathrm{F}$ hitung dibandingkan dengan $\mathrm{F}$ tabel. Nilai $\mathrm{f}$ pada hasil belajar adalah 4.588, nilai mean defference atau perbandingan rata-rata pada kelompok eksperimen - rata-rata kelompok kontrol adalah 35.90323 dan standar error difference adalah kesalahan pengukuran rata-rata. Pada nilai hasil belajar standar error diference adalah1.14544 dan nilai uji thasil belajar adalah sebesar 131.344.

\section{DAFTAR PUSTAKA}

Ali, M. 2007. Ilmu dan Aplikasi Pendidikan. . Padadogiana perss . Bandung

Anurrahman.2009. Belajar dan Pembelajaran.Alfabet. . Bandung

Bambang, W.2008. Teknologi Pembelajaran. Reneka Cipta. Jakarta

Barizi, A. 2009.Menjadi Guru Unggul.Ar-ruzz media. Jogjakarta.

Bermai, M. 2009. Desain Pembelajaran. Pustaka Insani Madani, Yogyakarta

Bodner, G. M. (1986). Constructivism: A Theory of Knowledge. Journal of Chemical Education. Vol. 63 (10) pp. 873-878

Chaeruman, Uwes A. (2008). Cognitive and Socio-Constructivism. Posted on October $13^{\text {th }}$, Teknologi Pendidikan.NET-Informasi Teknologi Pendidikan. [Online]. Tersedia: http://www.google.co.id. [9 Juni 2009].

Cheng, K.K., et. al. (2004). Using Online Homework System Enhances Student Learning of Physic Conception Introdustionary Physics Course. Amerika Journal of Physic. 72(11), 1447-1453

Daryanto.2009. Panduan Proses Pembelajaran.Publisher. Jakarta

Deni, R. 2008. Bahari Nusantara Untuk Kesejateraan Masayarakat Dan Ketahanan Nasional.MSCC. Jakarta 
Epon, N. 2009.Kompetensi Profesional Guru dalam Konteks Strategi Pembelajaran.Bina Nusantara. Bandung

Frankel, JR. (1980). Helping Students Think and Strategies for Teaching The Social Studies. 2nd ed. Englwood Cliff, NJ: Prentice-Hall Inc

Hadi, S. 2000. Metodologi Research. Andi Offset. Yogyakarta

Hasan, H. 1996. Pendidikan Ilmu Sosial.Dikti. Jakarta

Munadi, Y. 2008. Media Pembelajaran. . GP Press. Jakarta

Muslinch, M. 2007. KTSP. Bumi Aksara. Jakarta

Pasya, G, K 2006.Geografi.Pemahaman Konsep dan Metodologi. Bina Nusantara. Bandung.

Poendjiadi, A 2007. Sains Teknologi Masyarakat. Rosada. Bandung

Resni dalamhttp://resni.student.fkip.uns.ac.id/2009/11/21/macam-metode-dan-modelpembelajaran/Online tanggal 22-10-2010

Roestiyah. 2008. Strategi Belajar Mengajar. Rineka Cipta. Jakarta

Rusman. 2008. Menejemen Kurikulum. Rajawali Press. Jakarta

Sanjaya, W. 2009.Strategi Pembelajaran Berorientasi Standar Proses Pembelajaran. Kencana. Jakarta.

Sobary Sutikno. 2009. Belajar dan Pembelajaran. . Prospect . Bandung

Sudjana, N dan Rivai, A. 2007.Media Pengajaran. Bandung. Sinar Baru Algensindo

Sugiyono. 2009. Metode Penelitian Pendidikan. . Alfabeta. Bandung

Suharsimi. A. 2008. Dasar-dasar Evaluasi Pendidikan.Bumi Aksara. Jakarta

Sukardi. 2009. Metodologi Penelitian Pendidikan. Bumi Aksara. Jakarta.

Sumaatmadja, N. 1981.Studi Geografi.Alumni. Bandung 1997. Metodologi pengajaran Geografi.Bumi Aksara. Jakarta.

Trianto. 2010. Model Pembelajaran Terpadu. Bumi Aksara. Jakarta 